\title{
Reassessing carrier status for dystrophinopathies
}

\section{OPEN}

Tara M. Newcomb, MS Kevin M. Flanigan, MD

Correspondence to Dr. Flanigan: kevin.flanigan@

nationwidechildrens.org

\section{Neurol Genet}

2016;2:e108; doi: 10.1212/ NXG.0000000000000108
The cloning of the $D M D$ gene, and the identifications of mutations in it as the cause of Duchenne muscular dystrophy (DMD), makes a compelling story that is aptly told elsewhere. ${ }^{1}$ The locus-the largest in the human genome-consists of 79 exons, distributed over 2.5 million nucleotides on the $\mathrm{X}$ chromosome, which are assembled into a complementary DNA (cDNA) of around $14 \mathrm{~kb}$ encoding the predominant muscle isoform of the dystrophin protein. ${ }^{2}$ The size of the gene, and the number of exons, had historically made mutation analysis challenging. For more than a decade, the standard clinical assay was a multiplex PCR test that amplified sequences from a limited number of exons; nevertheless, because it included exons within the deletion hotspots of the gene, this method could confirm the presence of mutations in up to $98 \%$ of boys with exonic deletions. ${ }^{3,4}$

Although robust and economical, multiplex PCR testing was less than ideal. First, it left many patient mutations unidentified, as deletion mutations themselves only make about $65 \%$ of patients with the dystrophinopathies DMD or the milder Becker muscular dystrophy. ${ }^{5}$ Second, it did not assess all exons, leaving the extent of deletions undefined in many patients. Without the flanking exons defined, one cannot predict the reading frame of the resultant mRNA, which has implications for both prognosis ${ }^{6}$ and the prospects for enrollment in therapeutic trials of exon skipping directed at restoring the reading frame. ${ }^{7}$

The other major limitation of this test was the inability to detect mutations in carriers, who are heterozygous for exon copy number variation. Prior to the molecular era, determination of carrier status in nonobligate females depended on muscle histopathol$\mathrm{ogy}^{8}$; elevations of serum creatine kinase (CK), which is age-dependent and has a high false-negative rate'; or pedigree analysis of the DMD locus using restriction fragment length polymorphism ${ }^{10}$ or short tandem repeat polymorphisms, ${ }^{11}$ which may be inaccurate due to recombination within the large locus.
In their article in this issue, ${ }^{12}$ Bogue and Ramchandren describe the reassessment of carrier status in a large kindred affected by DMD after the detection of a mutation in the proband via a modern molecular method. The c.8660-2A $>\mathrm{T}$ mutation, which disrupts the exon 59 splice acceptor site, was detected in the proband by a method that allows direct sequencing of all 79 exons and their flanking intronic sequences. ${ }^{13}$ The proband's maternal grandmother had been told that she was not a carrier in the past, apparently based on serum CK levels, but she identified as a third cousin of the proband another patient in the clinic who was found to have the same mutation. Obligate carrier status could then be inferred for several other women who have been told that they either were not or were unlikely to be carriers.

The story of this pedigree is informative to the practicing clinician, as it highlights the need to be aware of continual improvements and methods of diagnosis, and to assess the era in which a patient's family received genetic counseling. Modern mutational analysis for DMD requires first an exon test that accurately assesses exon copy number of all 79 exons, allowing accurate characterization of the extent of both deletions and duplications, whether in probands or in related females. Adequate methods in current use include both multiplex ligation-dependent probe amplification ${ }^{14}$ and comparative genomic hybridization array ${ }^{15}$ techniques, but the important thing is the principle of complete quantitative characterization, and other methods may supplant these. In the absence of exon copy number variation, sequencing of all exons should occur by any of several methods. ${ }^{16}$ Using this approach, around $95 \%$ of all $D M D$ mutations can be detected, although the clinician should keep in mind that deep intronic mutations that result in mRNA alterations may require sequencing of muscle-derived cDNA to identify. ${ }^{17}$

As Bogue and Ramchandren point out, ${ }^{12}$ the "Duty to Reassess" is a topic of current discussion in the molecular genetics and genetic counseling fields. ${ }^{18}$ While many genetics providers are in favor 
of recontacting patients, there are significant barriers to implementing a routine process to recontact patients with updates to their genetic testing results. Tracking patients, their results, and their desire to receive new information takes significant time and effort and is unrealistic in most clinical practices. It can also present an ethical challenge when updates to interpretation or technology become available yet the patient is no longer actively followed by the ordering provider, or if the patient's desire for updated information has not been documented.

This case provides an excellent example of the importance of a detailed family history and careful assessment of previous genetic testing in revising the advice provided to a family. Not only was the proband provided with an accurate diagnosis with the help of family history, but additional family members were also provided with more accurate information about their own carrier status. Their report demonstrates a real-world example of appropriate reassessment and reminds the clinician of the need for careful attention to the basis of past genetic counseling advice.

\section{STUDY FUNDING}

No targeted funding reported.

\section{DISCLOSURE}

T.M. Newcomb has received research support from NICHD (R01HD69045) and CDC (U01DD001108). K.M. Flanigan has served on Scientific Advisory Boards for Audentes Therapeutics, Inc.; has served on the editorial boards of Neuromuscular Disorders, PLoS Currents Muscular Dystrophy, and Journal of Neuromuscular Disorders; holds Patents for US National Phase Patent Application Serial No. 14/785,769, "Recombinant Adeno-Associated Virus Delivery of Exon 2-Targeted U7snRNA Polynucleotide Constructs," and "Methods and Materials for Activating an Internal Ribosome Entry Site in Exon 5 of the DMD Gene"; has consulted for Sarepta Therapeutics, Inc., PTC Therapeutics, Inc., Marathon Pharmaceuticals, Inc., and Italafamico, Inc.; and has received research support from PTC Therapeutics, Akashi, Inc., Biomarin, Inc., Abeona Therapeutics, Inc., NIH/National Institute of Neurological Disorders and Stroke, Muscular Dystrophy Association, Parent Project Muscular Dystrophy, CureDuchenne, Association Francaise contre les Myopathies, A Cure For Kirby (The Children's Medical Research Foundation), Ben's Dream (The Sanfilippo Research Foundation), and A Life For Elisa (The Sanfilippo Children's Research Foundation). Go to Neurology.org/ng for full disclosure forms.

\section{REFERENCES}

1. Kunkel LM. 2004 William Allan Award address. Cloning of the DMD gene. Am J Hum Genet 2005;76:205-214.

2. Koenig M, Hoffman EP, Bertelson CJ, Monaco AP, Feener C, Kunkel LM. Complete cloning of the Duchenne muscular dystrophy (DMD) cDNA and preliminary genomic organization of the DMD gene in normal and affected individuals. Cell 1987;50:509-517.
3. Beggs AH, Koenig M, Boyce FM, Kunkel LM. Detection of $98 \%$ of DMD/BMD gene deletions by polymerase chain reaction. Hum Genet 1990;86:45-48.

4. Chamberlain JS, Gibbs RA, Ranier JE, Nguyen PN, Caskey CT. Deletion screening of the Duchenne muscular dystrophy locus via multiplex DNA amplification. Nucleic Acids Res 1988;16:11141-11156.

5. Dent KM, Dunn DM, von Niederhausern AC, et al. Improved molecular diagnosis of dystrophinopathies in an unselected clinical cohort. Am J Med Genet A 2005;134: 295-298.

6. Monaco AP, Bertelson CJ, Liechti Gallati S, Moser H, Kunkel LM. An explanation for the phenotypic differences between patients bearing partial deletions of the DMD locus. Genomics 1988;2:90-95.

7. Aartsma-Rus A, Fokkema I, Verschuuren J, et al. Theoretic applicability of antisense-mediated exon skipping for Duchenne muscular dystrophy mutations. Hum Mutat 2009;30:293-299.

8. Emery AE. Muscle histology in carriers of Duchenne muscular dystrophy. J Med Genet 1965;2:1-7.

9. Griggs RC, Mendell JR, Brooke MH, et al. Clinical investigation in Duchenne dystrophy: V. Use of creatine kinase and pyruvate kinase in carrier detection. Muscle Nerve 1985;8:60-67.

10. Bakker E, Hofker MH, Goor N, et al. Prenatal diagnosis and carrier detection of Duchenne muscular dystrophy with closely linked RFLPs. Lancet 1985;1:655-658.

11. Abbs S, Roberts RG, Mathew CG, Bentley DR, Bobrow M. Accurate assessment of intragenic recombination frequency within the Duchenne muscular dystrophy gene. Genomics 1990;7:602-606.

12. Bogue L, Ramchandren S. Outdated risk assessment in a family with Duchenne dystrophy: implications for duty to reassess. Neurol Genet 2016;2:e103. doi: 10.1212/NXG. 0000000000000103.

13. Flanigan KM, von Niederhausern A, Dunn DM, Alder J, Mendell JR, Weiss RB. Rapid direct sequence analysis of the dystrophin gene. Am J Hum Genet 2003;72: 931-939.

14. Schwartz M, Duno M. Improved molecular diagnosis of dystrophin gene mutations using the multiplex ligationdependent probe amplification method. Genet Test 2004; 8:361-367.

15. Hegde MR, Chin EL, Mulle JG, Okou DT, Warren ST, Zwick ME. Microarray-based mutation detection in the dystrophin gene. Hum Mutation 2008;29:1091-1099.

16. Nallamilli BR, Ankala A, Hegde M. Molecular diagnosis of Duchenne muscular dystrophy. Curr Protoc Hum Genet 2014;83:9.25.21-29.

17. Gurvich OL, Tuohy TM, Howard MT, et al. DMD pseudoexon mutations: splicing efficiency, phenotype, and potential therapy. Ann Neurol 2008;63:81-89.

18. Otten E, Plantinga M, Birnie E, et al. Is there a duty to recontact in light of new genetic technologies? A systematic review of the literature. Genet Med 2015;17: 668-678. 


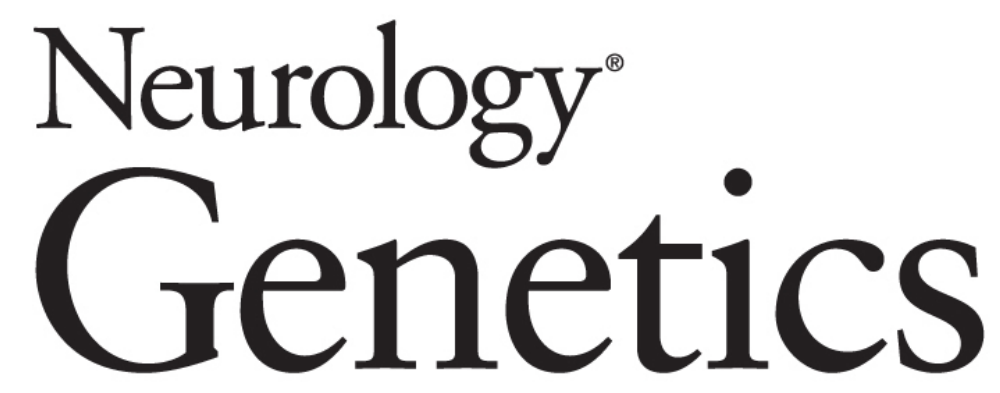

\section{Reassessing carrier status for dystrophinopathies \\ Tara M. Newcomb and Kevin M. Flanigan \\ Neurol Genet 2016;2; \\ DOI 10.1212/NXG.0000000000000108}

This information is current as of October 5, 2016

\section{Updated Information \& Services}

References

Citations

Permissions \& Licensing

Reprints including high resolution figures, can be found at: http://ng.neurology.org/content/2/5/e108.full.html

This article cites 18 articles, 2 of which you can access for free at: http://ng.neurology.org/content/2/5/e108.full.html\#\#ref-list-1

This article has been cited by 1 HighWire-hosted articles: http://ng.neurology.org/content/2/5/e108.full.html\#\#otherarticles

Information about reproducing this article in parts (figures,tables) or in its entirety can be found online at:

http://ng.neurology.org/misc/about.xhtml\#permissions

Information about ordering reprints can be found online: http://ng.neurology.org/misc/addir.xhtml\#reprintsus

Neurol Genet is an official journal of the American Academy of Neurology. Published since April 2015, it is an open-access, online-only, continuous publication journal. Copyright ( 2016 American Academy of Neurology. All rights reserved. Online ISSN: 2376-7839.

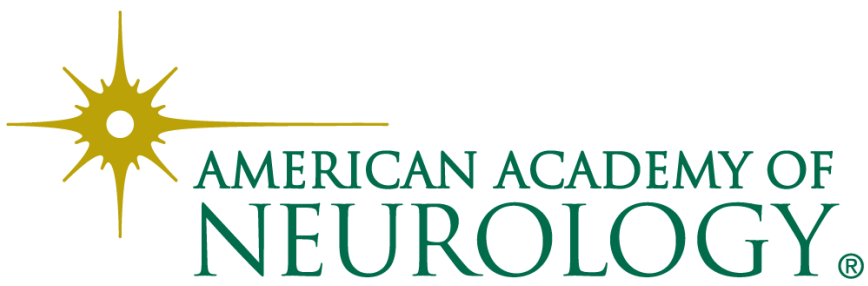

